\title{
Hemorrhagic Spinal Neuroenteric Cyst: A Case Report
}

\section{Romero $\mathrm{L}^{\text {** }}$, Arcos $\mathrm{A}^{1}$, González $\mathrm{L}^{1}$, Dominguez $\mathbf{M}^{1}$, Medina $\mathrm{JM}^{1}$, Arráez $\mathrm{MA}^{1}$ and Martínez $\mathrm{JV}^{2}$}

${ }^{1}$ Department of Neurosurgery, HRU Carlos Haya, Málaga, Spain

${ }^{2}$ Department of Neurosurgery, Maz Hospital, Zaragoza, Spain

\begin{abstract}
Introduction: Neuroenteric cysts are a rare type of spinal tumors that result of anomalies during embryonic development. A case with a rare haemorrhagic presentation is reported.

Case report: 42 years old male that shows an initial clinical picture consisting of cervical pain. Cervical Magnetic Resonance (MR) reveals a lesion intradural-extramedullar at level C2-C3. Findings are in correlation with hemorrhagic lesion in reabsorption phase. A surgical procedure is performed. Through a bilateral C2-C3 and partial C1 laminectomy the cyst was emptied. The rest of membranes are removed. The patient shows a progressively improvement. The hystopathological analyses find match neuroenteric cyst type A.
\end{abstract}

Discussion: 58 cases of neuroenteric spinal cysts reported in literature are analyzed. Total excision was performed in about $34 \%$. There was any finding about hemorrhagic presentation in neuroenteric cyst in these cases.

Keywords: Neuroenteric spinal cyst; Spinal cyst; Hemorrhagic spinal cyst

\section{Introduction}

Neuroenteric cysts are congenital anomalies that represent about $1 \%$ of spinal tumors [1]. They appear as the result of an incorrect splitting of notochord during third week of embryonic development, remaining heterotopic cells of gastrointestinal or respiratory epithelium. These cells may group together establishing a cyst lesion that causes medullar compression. In the literature about $50 \%$ are associated with other spinal congenital anomalies like spinal dysraphisms or scoliosis [2]. Neuroenteric cysts might be classified according to histopathological characteristics in three types such A, B or C [3]. About $95 \%$ of these lesions are intradural-extramedullary, half of them in cervical location [4]. In present study, a case of neuroenteric spinal cyst with a rare hemorrhagic presentation in cervical location is reported. Furthermore, a literature review is performed.

\section{Case Report}

42 year old male presents a clinical picture consisting of cervical pain extending to the right upper limb. He also refers paresthesias in both upper limbs that progressed intensely in about 2-3 months. In neurological examination are noticed) bicipital hyper-reflexia and generalized hypoesthesia in both upper limbs without metameric definition. No evidence of weakness. Progress of our patient leads right hemiparesis, predominantly in right upper limb.

Cervical Magnetic Resonance (MR) reveals a $2 \times 1 \times 3 \mathrm{~cm}$ lesion, intradural-extramedullary in anterior location, causing medullar compression at level C2-C3, without any other pathologic findings. The lesion shows hyper intensity on T1-weighted images. Patient is moved to our hospital from other center. When he arrived, a new MR is performed, 15 days later. It reveals the described lesion showing hypo intensity on T1-weighted images and hyper intensity on T2 weighted images, brighter than cerebrospinal fluid. This last MR also shows a liquid level hyper intense compared to cyst content on T1-weigthed images and hypo intense on T2-weigthed images (Figure 1). Findings in both MR are in correlation with hemorrhagic lesion in reabsorption phase.

A surgical procedure is performed, carried out by intraoperative neurophysiological monitoring to ensure total removal. Through a bilateral C2-C3 and partial C1 laminectomy the cyst gets emptied. The rest of membranes are removed as well (Figure 2). No signs of cervical instability were showed.
The patient improves progressively with persistence of slight hypoesthesia in both upper limbs.

Histopathological analyses show a single layer of pseudo stratified columnar or cuboidal cells mimicking respiratory or gastrointestinal epithelium. This find matches with neuroenteric cyst type A (Table

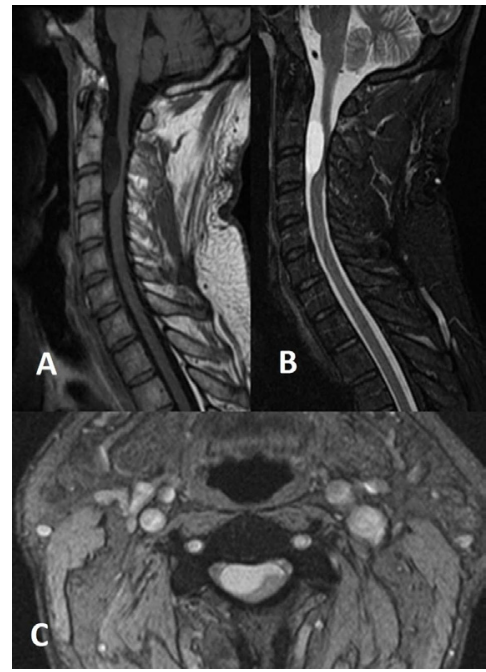

Figure 1: Figure 1. Cervical MR: lesion of $2 \times 1 \times 3 \mathrm{~cm}$ hypointense on T1-weighted images and hyperintense on T2 weighted images, intraduralextramedullary, at level C2-C3. Sagittal T1 sequence (A). Sagittal T2 sequence (B). Axial T2 sequence (C).

*Corresponding author: Lorena Romero Moreno, Department of Neurosurgery HRU Carlos Haya, Málaga, Spain, Tel: +0034606204494; Fax: +0034951291145; E-mail: Iorenaromeromoreno@gmail.com

Received December 02, 2011; Accepted January 10, 2012; Published January 15,2012

Citation: Romero L, Arcos A, González L, Dominguez M, Medina JM, et al. (2012) Hemorrhagic Spinal Neuroenteric Cyst: A Case Report. J Spine 1:108 doi:10.4172/2165-7939.1000108

Copyright: $\odot 2012$ Romero L, et al. This is an open-access article distributed under the terms of the Creative Commons Attribution License, which permits unrestricted use, distribution, and reproduction in any medium, provided the original author and source are credited. 
Citation: Romero L, Arcos A, González L, Dominguez M, Medina JM, et al. (2012) Hemorrhagic Spinal Neuroenteric Cyst: A Case Report. J Spine 1:108. doi:10.4172/2165-7939.1000108

Page 2 of 3

1). Immunohistochemical findings: positive CEA, EMA, KAEI-AE3, vimentin and PAS; negative PAFG and S-100.

Six months after surgery the patient shows improvement of paresthesias in both upper limbs. It persists clumsiness when performing precision movements with hands. Control MR reveals complete cyst resection without evidence of recurrence (Figure 3).

\section{Discussion}

There aren't any findings in the literature about hemorrhagic

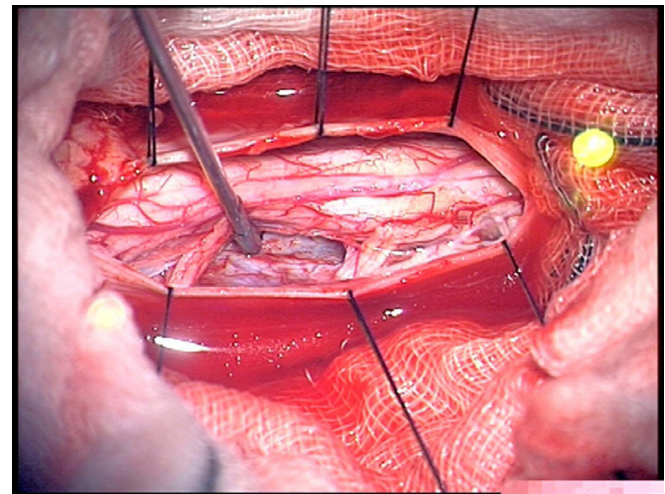

Figure 2: Intraoperative image.

\begin{tabular}{|l|l|l|l|}
\hline Characteristics & Type A & Type B & Type C \\
\hline $\begin{array}{l}\text { Single layer of pseudostratified columnar } \\
\text { or cuboidal cells mimicking respiratory or } \\
\text { gastrointestinal epithelium }\end{array}$ & + & + & + \\
\hline $\begin{array}{l}\text { Complex invaginations with glandular } \\
\text { organization, mucinous or serous } \\
\text { production; nerve ganglion, lymphoid, } \\
\text { skeletal muscle, smoothmuscle, fat, } \\
\text { cartilage and/or bone elements }\end{array}$ & - & & \\
\hline Ependimal or glial tissue & - & - & \\
\hline
\end{tabular}

Ependimal or glial tissue

Table1:

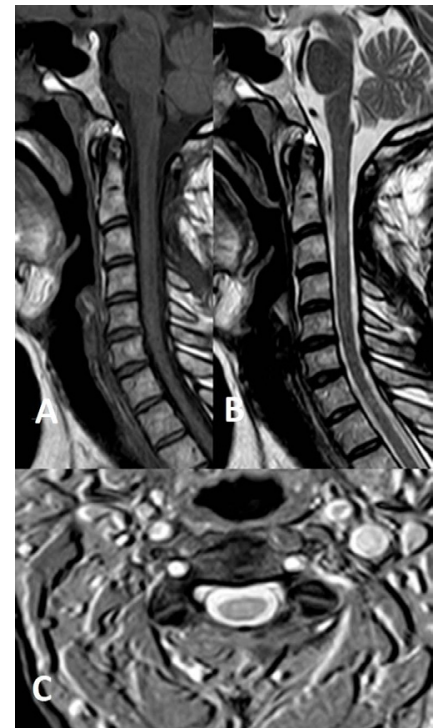

Figure 3: Cervical MR after surgery: complete cyst resection without evidence of recurrence. Sagittal T1 sequence (A). Sagittal T2 sequence (B). Axial T2 sequence $(C)$

\begin{tabular}{|l|l|l|l|l|l|}
\hline Author, year & Cases & Location & $\begin{array}{l}\text { Total } \\
\text { excision }\end{array}$ & $\begin{array}{l}\text { Partial } \\
\text { excision }\end{array}$ & $\begin{array}{l}\text { Recurre } \\
\text { nces }\end{array}$ \\
\hline Rivierez et al., 1989 [8] & 1 & Thorax & 0 & 1 & - \\
\hline Brooks et al., 1993 [9] & 9 & $\begin{array}{l}\text { 5C, 3T, } \\
\text { 1L }\end{array}$ & 2 & 6 & - \\
\hline Rivierez et al., 1997 [10] & 1 & Lumbar & 0 & 1 & - \\
\hline Lippman et al., 2001[11] & 1 & Thorax & 0 & 1 & - \\
\hline Singhal et al., 2001 [1] & 1 & Thorax & 1 & 0 & - \\
\hline Kumar et al., 2002 [6] & 6 & $\begin{array}{l}\text { 2C, 1T, } \\
\text { 3L }\end{array}$ & 2 & 4 & - \\
\hline Kumar et al., 2002 [6] & 1 & Thorax & 0 & 1 & - \\
\hline Paolini et al., 2003 [12] & 1 & Thorax & 0 & 1 & - \\
\hline Mezenes et al., 2006 [5] & 10 & $\begin{array}{l}\text { 8C, 1T, } \\
\text { 1L }\end{array}$ & - & - & 2 \\
\hline Shane et al., 2006 [13] & 1 & Cervical & - & - & - \\
\hline Nagi et al., 2007 [14] & 1 & Cervical & 0 & 1 & - \\
\hline Garg et al., 2008 [7] & 23 & $\begin{array}{l}\text { 12C, 9T, } \\
\text { 2L }\end{array}$ & 14 & 9 & 5 \\
\hline Theret et al., 2010 [2] & 1 & Cervical & 0 & 1 & - \\
\hline Ziu et al., 2010 [4] & 1 & Thorax & 1 & 0 & - \\
\hline
\end{tabular}

Table 2:

presentation of neuroenteric cyst [1-14]. The clinical picture is generally gradual, with progressively increasing of symptoms. This could be explained by several periodic ruptures of the cyst, increasing cyst size due to weather osmotic or hemodynamic factors such as venous stasis with thrombosis, abnormal process of formation and resorption of mucin, obstruction or hemorrhage into the cyst [5].

Neuroenteric cyst usually shows iso- to hypo intense T1- weighted appearance and presents hyper intense T2-weighted appearance. Occasionally, T1 hyper intensity might be seen according to the amount of the cyst protein content, or else, in rare cases, when intracystic hemorrhage appears. These lesions seldom enhance to contrast. CT is the indicated image test for evaluation of a concomitant vertebral abnormality [4].

A correct differential diagnosis has to be done taking into account: arachnoid cyst, ependymal cyst, epidermoid and dermoid cyst, teratoma, teratoid tumor and sirinx $[4,6]$.

The basis of treatment for these lesions is decompression of neural element by surgical excision, preferably total excision. However, this is not always feasible [7]. In the literature, a review of 58 cases showed that total excision was performed in about $34 \%$ of the cases $[1,2,4$ 14] (Table 2). Despite their typical ventral or ventrolateral location, the majority of neuroenteric cysts have been approached via dorsal/ posterior laminectomy. Few reports express support for the proposal of a ventral approach in cases of ventral location to get easier a total excision [5]. Other alternatives in intramedullary cyst surgeries ranged from cyst aspiration to subtotal resection with cyst marsupialization or cystosubaracnoid shunting [2].

\section{References}

1. Singhal BS, Parekh HN, Ursekar M, Deopujari CE, Manghani DK (2001) Intramedullary neurenteric cyst in mid thoracic spine in an adult: a case report. Neurol India 49: 302-304.

2. Theret E, Litre CF, Lefebvre F, Eap C, Scherpereel B, et al. (2010) Huge intramedullar neurenteric cyst with intrathoracic development in a 1 month-old boy: excision though the anterior approach. A case report and review of the literature. Acta Neurochir (Wein) 152: 481-483.

3. Savage JJ, Casey JN, McNeill IT, Sherman JH (2010) Neuroenteric cysts of the spine. J Craniovertebr Junction Spine 1: 58-63.

4. Ziu M, Vibhute P, Vecil GG, Henry J (2010) Isolated spinal neurenteric cyst 
presenting as intramedullary calcified cystic mass on imaging studies: case report and review of literature. Neuroradiology 52: 119-123.

5. Menezes AH, Traynelis VC (2006) Spinal neurenteric cysts in the magnetic resonance imaging era. Neurosurgery 58: 97-105.

6. Kumar R, Nayak SR (2002) Unusual neuroenteric cysts: diagnosis and management. Pediatr Neurosurg 37: 321-330.

7. Garg N, Sampath S, Yasha TC, Chandramouli BA, Devi BI, et al. (2008) Is total excision of spinal neurenteric cysts possible? Br J Neurosurg 22: 241-251.

8. Rivierez M, Duclos H, Piekarski JD, Foncin JF, Cornu P, et al. (1989) Intramedullary neurenteric cyst without an associated malformation. Case report. Neurochirurgie 35: 191-195.

9. Brooks BS, Duvall ER, el Gammal T, Garcia JH, Gupta KL, et al. (1993) Neuroimaging features of neurenteric cysts: analysis of nine cases and review of the literature. AJNR Am J Neuroradiol 14: 735-746.
10. Rivierez M, Buisson G, Kujas M, Ridarch A, Mignon E, et al. (1997) Intramedullary neurenteric cyst without any associated malformation. One case evaluated by RMI and electron microscopic study. Acta Neurochir (Wien) 139 887-890.

11. Lippman CR, Arginteanu M, Purohit D, Naidich TP, Camins MB (2001) Intramedullary neurenteric cysts of the spine: case report and review of the literature. J Neurosurg 94: 305-309.

12. Paolini S, Ciappetta P, Domenicucci M, Guiducci A (2003) Intramedullary neurenteric cyst with a false mural nodule: case report. Neurosurgery 52: 243246.

13. Tubbs RS, Salter EG, Oakes WJ (2006) Neurenteric Cyst: case report and a review of the potential dysembryology. Clin Anat 19: 669-672.

14. Nagi S, Ghorbel D, Drissi C, Maatallah Y, Hammami N, et al. (2007) Intramedullary neurenteric cyst without concurrent malformation. Australas Radiol 51: B14-B17. 